\title{
DUKUNGAN INFORMASI DARI KELUARGA DAPAT MENINGKATKAN KUALITAS HIDUP LANSIA HIPERTENSI
}

\author{
Agnes Dewi Astuti \\ Poltekkes Kemenkes Palangka Raya
}

\begin{abstract}
ABSTRAK
Jumlah lansia hipertensi di Puskesmas Jekan Raya meningkat. Pengamatan lapangan, keluarga kurang memberikan dukungan dalam pengendalian hipertensi, sehingga menganggap sembuh jika tekanan darah lansia menurun. Tujuan penelitian mengetahui hubungan dukungan keluarga dengan kualitas hidup lansia. Desain menggunakan cross sectional pada 108 lansia dan keluarga, dengan teknik klaster proporsional. Hasil menunjukkan ada hubungan dukungan keluarga dengan kualitas hidup lansia. Salah satu elemen dukungan keluarga berhubungan bermakna adalah dukungan informasi setelah dikontrol dengan pendidikan, penghasilan, asuransi kesehatan. Direkomendasikan pada pengambil keputusan keperawatan lansia agar meningkatkan program kesehatan lansia berbasis keluarga untuk meningkatkan kualitas hidup lansia melalui pemberian informasi tentang kesehatan bagi lansia.
\end{abstract}

Kata kunci : lansia, infomasi, keluarga, kualitas hidup.

\begin{abstract}
Number of elderly hypertension was increased in Jekan Raya Public Health Center. Field observations, less family support in the control of hypertension, so consider elderly cured if blood pressure decreased. The purpose of this research was determined the correlation of family support quality of life of the elderly. Used crosssectional design in 108 elderly and families, with a proportional cluster technique. Results showed correlation of family support with quality of life of elderly. One of the elements related to family support is information $(p=0.000)$ after controlled by education, income, health insurance. Recommended in elderly nursing decision makers in order to improve the health of the elderly family-based programs to improve the quality of life of the elderly with health information for elderly.
\end{abstract}

Keywords: elderly, information, family, quality of life. 


\section{Latar Belakang}

Penuaan merupakan suatu proses dalam kehidupan terjadi secara alami dan dihadapi oleh setiap manusia. Penuaan ditandai dengan hilangnya secara perlahan-lahan kemampuan jaringan organ tubuh memperbaiki diri dan bersifat irreversibel. Lansia merupakan tahapan akhir dari siklus kehidupan seseorang dan mengalami proses penuaan dengan terjadinya perubahan-perubahan pada berbagai aspek fisik atau fisiologi, psikologi, dan sosial (Miller, 2004). Perubahan tersebut akibat proses penuaan lansia yang kompleks, sehingga lansia berpeluang sangat besar untuk mengalami penyakit daripada kelompok umur yang lain dan termasuk ke dalam kelompok rentan (vulnerable population) (Stanhope \& Lancaster, 2004).

Menurut Lakatta (2000 dalam Miller, 2004), sistem kardiovaskular mampu beradaptasi terhadap proses penuaan pada lansia seperti pada jantung terjadi hipertrofi miokardial sehingga meningkatkan tekanan pada arteri. (Anderson \& McFarlane, 2011). Menurut teori konsekuensi Miller (2004) diketahui bahwa gangguan sistem kardiovaskular yang terjadi pada lansia akibat proses penuaan diperkuat juga oleh adanya faktor risiko yaitu obesitas (kegemukan), kebiasaan merokok, konsumsi diet yang tinggi lemak dan natrium serta ketidakmampuan dalam beraktifitas menimbulkan konsekuensi fungsional negatif pada lansia.

Kasus hipertensi di wilayah kerja Puskesmas Jekan Raya Kota Palangka Raya mengalami peningkatan setiap tahunnya. Hal ini disebabkan karena banyak lansia dan keluarga yang mengabaikan atau kurang memahami tentang pengendalian hipertensi sehingga cenderung menganggap sembuh jika tekanan darah pada lansia sudah menurun. Menurut Miller (2004), jika seseorang yang mengalami hipertensi yang terus menerus dan tidak mendapatkan pengobatan dan pengontrolan secara tepat dapat menyebabkan jantung seseorang bekerja ekstra keras, akhirnya kondisi tersebut berakibat terjadinya kerusakan pada pembuluh darah jantung, ginjal, otak, dan mata hingga berisiko terjadinya penyakit jantung koroner, dan stroke Kondisi tersebut dapat menurunkan kualitas hidup lansia.

Kualitas hidup mempunyai hubungan yang signifikan terhadap angka kesakitan, kematian dan mempengaruhi usia harapan hidup lansia serta mempengaruhi kapasitas fungsional, psikologi kesehatan sosial dan kesejahteraan lansia hipertensi. Menurut Isa dan Baiyuwe (2006) dan Goz et.al (2007), kualitas hidup adalah pandangan atau persepsi individu yang multidemensi terhadap kehidupannya dalam konteks budaya dan nilai yang dianut oleh individu dalam hubungannya dengan tujuan hidup individu, harapan, standar, perhatian, kesehatan, kesejahteraan yang mempengaruhi kemampuan fisik, psikologis, tingkat kemandirian, hubungan sosial dan lingkungan serta kemampuan kognitif (kepuasan) dan komponen emosional/ kebahagiaan.

Faktor yang dapat mempengaruhi kualitas hidup seseorang antara lain jensi kelamin, 
pendidikan, penghasilan, pekerjaan, kepemilikan asuransi kesehatan (Nazir, 2006 \& Ayalon et. al., 2006).

Kualitas hidup pada lansia dipengaruhi oleh proses penuaan.dimana terjadi penurunan kemampuan tubuh untuk beradaptasi dengan stres lingkungan (Pujiastuti, 2003 dalam Effendi, 2009). Menurut Nazir (2006), kondisi tersebut dapat membuat kualitas hidup lansia semakin menurun, sehingga lansia memerlukan suatu dukungan sosial yang dapat meningkatkan kondisi lansia menjadi lebih baik dan membutuhkan sistem pendukung dari berbagai pihak baik keluarga, orang terdekat maupun tenaga kesehatan. Dukungan sosial yang dapat diberikan oleh keluarga (dukungan keluarga) kepada lansia adalah suatu sistem pendukung bagi anggota keluarganya yang mengalami situasi stres sehingga dapat memberikan kenyamanan fisik dan psikologis (Taylor, 2006).

Berdasarkan fenomena hipertensi pada lansia dan pentingnya dukungan keluarga kepada lansia dalam upaya meningkatkan kualitas hidup lansia, maka dapat dirumuskan pertanyaan penelitian yaitu: "Adakah hubungan dukungan informasi dari keluarga dengan kualitas hidup lansia hipertensi di wilayah kerja Puskesmas Jekan Raya ?”

Tujuan penelitian ini adalah untuk mengetahui hubungan dukungan informasi keluarga dengan kualitas hidup lansia hipertensi di wilayah kerja Puskesmas Jekan Raya Kota Palangka Raya.

\section{Tinjauan Teoritis}

Lansia merupakan populasi rentan yang lebih besar kemungkinannya untuk mengalami masalah kesehatan akibat paparan berbagai risiko lebih tinggi/ rentan daripada populasi yang lainnya (Stanhope \& Lancaster, 2004). Kerentanan bersifat multidimensi yaitu dipengaruhi oleh faktor keterbatasan sumber daya, faktor perubahan status kesehatan, faktor risiko kesehatan, faktor marjinalisasi. Kondisi tersebut dapat mempengaruhi tingkat kualitas hidup lansia dalam menjalani masa tuanya.

Kualitas hidup (Quality of Life) adalah persepsi individu terhadap posisi mereka dalam kontek budaya serta nilai, tujuan hidup, harapan, standar dan perhatian. Hal ini merupakan konsep yang luas dan dapat mempengaruhi kesehatan fisik, psikologis, tingkat ketergantungan, hubungan sosial, keyakinan personal dan hubungannya dengan keinginan di masa yang akan datang terhadap lingkungan mereka (WHO dalam Isa \& Baiyewu, 2006).

Menurut House (1981, Peterson \& Bredow, 2004), Pender (1996) dan Syam'ani (2011), peran penting keluarga dalam dukungan sosial tersebut dapat terlihat dari empat domain dukungan berupa dukungan informasional, dukungan penghargaan, dukungan instrumental, dukungan emosional dan dukungan spiritual.

Dukungan informasi merupakan dukungan yang diberikan keluarga mencakup pemberian informasi, pengetahuan, nasehat atau saran, 
petunjuk, umpan balik sehingga individu dapat membahas masalahnya dan mencoba mencari jalan keluar untuk memecahkan masalahnya. Dukungan ini dapat menahan menunculnya suatu stressor karena informasi yang diberikan dapat menyumbangkan sugesti yang khusus pada lansia (Pender, 1996; Taylor, 2006; House, 1981 dalam Peterson \& Bredow, 2004).

Dukungan informasi yang diberikan keluarga merupakan salah satu bentuk fungsi perawatan keluarga terhadap anggota keluarganya termasuk pada lansia. Fungsi perawatan kesehatan keluarga merupakan fungsi keluarga dalam memenuhi kebutuhan fisik seperti makanan, pakaian, tempat tinggal dan perawatan kesehatan. Keluarga juga dapat memberikan promosi kesehatan dan perawatan kesehatan preventif, serta berbagi perawatan bagi anggota yang sakit (Friedman, Bowden \& Jones, 2003).

Penelitian yang dilakukan oleh Zulfitri (2006), ditemukan adanya hubungan antara dukungan informasi keluarga dengan perilaku lansia hipertensi dalam mengontrol kesehatannya. Penelitian Herlinah, Wiwin dan Rekawati (2011), juga mengungkapkan bahwa dukungan informasi dalam keluarga dapat meningkatkan perilaku sehat lansia dalam pengendalian hipertensi.

\section{Metode Penelitian}

Rancangan penelitian yang digunakan dalam penelitian kuantitaif ini adalah desain descriptive correlational dengan menggunakan pendekatan cross sectional study. Populasi penelitian ini adalah seluruh lansia (berusia lebih dari 60 tahun) yang menderita hipertensi dan terdaftar di wilayah kerja puskesmas Jekan Raya Kota Palangka Raya dan tinggal bersama keluarga sebagai care giver utama sebanyak 108 lansia dan keluarga dengan jumlah sampel sebanyak 108 lansia dan keluarga.

Pemilihan sampel pada penelitian ini adalah dengan cara probability sampling. Pengambilan sampel dengan cluster sampling karena sampel diambil dalam satu wilayah yang populasinya tersebar luas yaitu wilayah kerja puskesmas Jekan Raya Kota Palangka Raya (Sastroasmoro \& Ismail, 2010). Teknik pengambilan sampel diawali dengan pembuatan kode nomor pada sampel frame (dafar nama populasi untuk setiap pustu dan puskesdes) sesuai dengan jumlah populasi lansia hipertensi adalah sebanyak 138. Selanjutnya dari setiap pustu/puskesdes, nomor sampel diundi dan diambil sesuai dengan perhitungan sampel secara proporsional sebanyak 108.

Alat pengumpulan data penelitian ini menggunakan kuesioner yang terdiri dari 3 kuesioner yaitu kuesioner karakteristik lansia, kuesioner dukungan keluarga dan kuesioner kualitas hidup. Kuesioner kualitas hidup lansia merupakan komposit dari 4 domain penilaian kualitas hidup yaitu domain fisik, psikologis, hubungan sosial dan lingkungan.

Analisis data pada penelitian ini dilakukan dengan analisis univariat deskriptif, analisa hubungan bivariat dan analisa multivariat 
untuk menentukan variabel independent paling dominan setelah dikontrol dengan variabel perancu. Analisa bivariat meggunakan uji chi square, sedangkan analisa multivariat menggunakan uji regresi logistik berganda.

\section{Hasil Penelitian}

Hasil penelitian didapatkan gambaran karakteristik sebagai berikut : 60-65 tahun adalah sebanyak $70,4 \%$, dengan karakteristik responden sebagian besar berjenis kelamin perempuan yaitu sebanyak $80,6 \%$, tingkat pendidikan rendah lebih dari separuh yaitu $67,6 \%$. Responden yang memiliki pendapatan yang lebih dari pendapatan minimum (UMK Palangka Raya tahun 2013) yaitu Rp. 1.300.000,- dikategorikan dalam pendapatan tinggi sebanyak $53,7 \%$ dengan jumlah responden lebih dari separuh tidak bekerja sebanyak $62 \%$ dan lebih dari separuh memiliki asuransi kesehatan berupa jamkesmas maupun askes yaitu sebesar $65,7 \%$.

Hasil analisis hubungan dukungan informasi keluarga dengan kualitas hidup lansia yaitu lansia yang mendapatkan dukungan informasi yang baik dari keluarga, memiliki kualitas hidup yang tinggi 81,7\% dibandingkan dengan lansia yang mempunyai dukungan informasi yang kurang baik $37,5 \%$. Hasil uji hipotesis Chi Square dua sisi (2-sided) diperoleh nilai $p=0,000$ berarti lebih kecil dari nilai $\alpha=0,05$, maka dapat disimpulkan ada hubungan yang signifikan antara dukungan informasi keluarga dengan kualitas hidup lansia. Dari hasil analisis diperoleh pula nilai $\mathrm{OR}=7,42$ (CI $95 \% ; 3,09: 17,85)$ artinya keluarga yang memberikan dukungan informasi yang baik pada lansia berpeluang 7,42 kali untuk menyebabkan kualitas hidup lansia tinggi dibandingkan dengan yang kurang baik dalam memberikan dukungan informasi.

\section{Pembahasan}

Hasil penelitian pada kualitas hidup lansia hipertensi di wilayah kerja Puskesmas Jekan Raya Kota Palangka Raya tahun 2013 menunjukkan bahwa lebih dari separuh lansia hipertensi memiliki kualitas hidup yang tinggi yaitu sebanyak 67 lansia hipertensi (62\%).

Hasil analisis hubungan dukungan informasi keluarga dengan kualitas hidup lansia hipertensi di wilayah kerja Puskesmas Jekan Raya Kota Palangka Raya tahun 2013 menunjukkan bahwa ada hubungan dukungan informasi keluarga dengan kualitas hidup lansia hipertensi $(p=0,000)$ yaitu dengan data lansia memiliki kualitas hidup yang tinggi dengan keluarga yang memberikan dukungan informasi baik $(81,7 \%)$, lebih tinggi dibandingkan dengan lansia yang berkualitas hidup tinggi namun dengan dukungan informasi keluarga yang kurang baik $(37,5 \%)$. Keluarga yang memberikan dukungan informasi yang baik pada lansia memberikan peluang 7,424 kali meningkatkan kualitas hidup lansia hipertensi dibandingkan dengan yang kurang baik dalam memberikan dukungan informasi. Hal tersebut menunjukkan bahwa keluarga yang mempunyai kemampuan dalam memberikan dukungan informasi yang baik pada lansia 
hipertensi akan berkontribusi dalam peningkatan kualitas hidup lansia hipertensi.

Hasil penelitian ini sejalan dengan penelitian yang dilakukan Zulfitri (2006) bahwa ada hubungan dukungan informasi yang diberikan keluarga untuk lansia dengan perilaku lansia hipertensi dalam mengontrol kesehatannya, selain itu dukungan informasi dalam keluarga dapat meningkatkan perilaku sehat lansia dalam pengendalian hipertensi (Herlina, Wiwin dan Rekawati, 2011). Hal ini berhubungan pula dengan hasil penelitian yang dilakukan Amigo, Sahar, Sukihananto (2012) menunjukkan pendidikan keluarga merupakan variabel yang paling dominan terhadap status kesehatan pada aggregate lansia dengan hipertensi. Pendidikan keluarga yang baik tentang hipertensi dapat mendukung keluarga dalam memberikan informasi tentang kesehatan terutama tentang kesehatan hipertensi sehingga dapat mendukung lansia mencapai kondisi kesehatan yang optimal.

Berdasarkan teori, lansia dengan hipertensi mengalami keterbatasan dalam memecahkan masalah kesehatannya sehingga dukungan yang dapat diberikan oleh keluarga berupa pemberian informasi, pengetahuan, nasehat atau saran, petunjuk, umpan balik sehingga lansia bersama keluarga dapat membahas masalahnya dan mencoba mencari jalan keluar untuk pemecahannya. Dukungan ini diharapkan dapat menahan munculnya stressor yang lebih berat bagi lansia (Pender, 1996; Taylor, 2006; House, 1981 dalam Peterson \& Bredow, 2004).
Menurut analisis peneliti, hasil penelitian yang dilakukan sebelumnya menunjukkan bahwa dukungan berupa informasi dari keluarga bagi lansia sangat berkaitan dengan kepatuhan dan pengendalian hipertensi pada lansia. Demikian pula dengan kondisi dukungan keluarga lansia hipertensi di wilayah kerja Puskesmas Jekan Raya Kota Palangka Raya. Beberapa hal yang telah membantu keluarga dan lansia dalam mendapatkan informasi tentang masalah hipertensi secara mendalam yaitu dengan cara mengeksplorasi dari beberapa media seperti televisi dan koran lokal yang memaparkan tentang kesehatan lansia minimal 1 minggu sekali, ketersediaan internet yang bisa di akses dengan mudah setiap hari, serta buku dan majalah yang bisa didapatkan di toko buku terdekat.

Pendidikan kesehatan juga diberikan secara langsung oleh petugas kesehatan yang ada di sarana pelayanan kesehatan maupun saat melakukan kunjungan rumah. Petugas kesehatan juga memfasilitasi lansia dan keluarga dalam mendapatkan informasi tentang perawatan kesehatan hipertensi walaupun masih belum optimal. Kegiatan praktik klinik keperawatan yang dilakukan oleh mahasiswa D3 keperawatan, juga turun membantu dalam upaya mencapai kondisi kesehatan lansia yang optimal melalui informasi kesehatan yang diberikan.

Kemampuan keluarga dalam memberikan dukungan informasi bagi lansia memerlukan perhatian dari semua pihak terutama dari tenaga keperawatan kesehatan melalui 
intervensi keperawatan. Intervensi keperawatan yang bisa dilakukan adalah dengan pendidikan kesehatan bagi keluarga tentang hipertensi pada lansia, terapi-terapi yang dapat diajarkan kepada keluarga dalam membantu lansia menurunkan tekanan darahnya misalnya senam lansia, manajemen nutrisi bagi lansia hipertensi serta dukungan penyediaan informasi yang mudah, murah dan terjangkau bagi lansia dan keluarga di sarana pelayanan kesehatan.

\section{Kesimpulan}

Hasil penelitian yang telah dilakukan dapat disimpulkan bahwa :

1. Kualitas hidup lansia hipertensi di wilayah kerja Puskesmas Jekan Raya Kota Palangka Raya lebih dari separuh tergolong tinggi.

2. Ada hubungan dukungan informasi dengan kualitas hidup lansia hipertensi. Dukungan informasi yang berkontribusi dalam meningkatkan kualitas hidup lansia berupa penyediaan informasi kesehatan bagi lansia yang mudah, murah dan terjangkau bagi lansia di sarana pelayanan kesehatan serta di dalam masyarakat.

3. Lansia dengan dukungan informasi keluarga yang baik berpeluang 7,424 kali memiliki kualitas hidup yang tinggi dibandingkan lansia yang mendapatkan dukungan informasi keluarga yang kurang baik setelah dikontrol oleh variabel pendidikan, pendapatan, askes.

\section{Saran}

\section{Untuk Pelayanan kesehatan}

a. Untuk Dinas Kesehatan

1) Membuat kebijakan pelaksanaan perkesmas berbasis dukungan keluarga.

2) Menerapkan program puskesmas santun lansia dan dengan melakukan pembinaan pada puskesmas-puskesmas di bawah wilayah dinas kesehatan.

b. Untuk Kepala Puskesmas

1) Memberikan uraian tugas yang jelas kepada perawat (perkesmas) dan penambahan perawat untuk kegiatan di luar gedung serta melakukan suvervisi ke keluarga atau masyarakat.

2) Melakukan pembinaan posyandu di bawah wilayah kerja puskesmas dan pembinaan dalam keluarga sebagai sumber informasi bagi lansia dan keluarga.

c. Untuk Perawat Kesehatan Masyarakat

1) Meningkatkan pengetahuan dan kemampuan dalam intervensi keperawatan bagi lansia hipertensi dan keluarga sebagai upaya promotif (misalnya dengan pendidikan kesehatan tentang manajemen nutrisi lansia hipertensi); upaya preventif (misalnya dengan pendidikan kesehatan tentang latihan asertif); kuratif (misalnya dengan pendidikan kesehatan tentang 
pemberian obat secara tepat dan benar bagi lansia hipertensi) dan rehabilitatif (misalnya dengan terapi keluarga, konseling, teknik nafas dalam dan relaksasi) dengan melibatkan keluarga dan masyarakat.

2) Memfasilitasi pelatihan bagi kader kesehatan posyandu lansia untuk meningkatkan kualitas pelayanan di posyandu bagi lansia dan pembentukan posyandu di wilayah kerja puskesmas yang belum ada.

d. Untuk Keluarga dan Lansia

1) Keluarga lebih meningkatkan pengetahuan dengan aktif mencari informasi kesehatan dari berbagai sumber tentang perawatan kesehatan hipertensi pada lansia.

2) Keluarga meningkatkan kemampuan dalam memberikan dukungan keluarga khususnya dukungan infomasi bagi lansia dengan diskusi dalam keluarga tentang kesehatan lansia, melibatkan lansia dalam musyawarah keluarga dan kegiatan yang diadakan di masyarakat dan serta menerima kondisi lansia apa adanya dengan segala kondisi dan keterbatasannya.

3) Keluarga berperan aktif dalam upaya kesehatan dalam meningkatkan kualitas hidup lansia dengan mengikuti kegiatan yang diselenggarakan oleh tenaga kesehatan di rumah maupun di masyarakat misalnya berperan aktif sebagai kader kesehatan posyandu lansia, terlibat aktif dalam intervensi keperawatan yang dilakukan tenaga kesehatan untuk meningkatkan dukungan keluarga khususnya dukungan penghargaan keluarga.

4) Lansia lebih aktif dalam mengikuti kegiatan keluarga maupun di masyarakat misalnya melalui keikutsertaan dalam kegiatan posyandu, kegiatan keagamaan, acara adat pernikahan dan perkumpulan lansia sehat dan bahagia.

5) Lansia hipertensi lebih berusaha dalam upaya meningkatkan kesehatan dan kebugaran fisik melalui kegiatan olah raga, senam, jalan santai sehingga mencapai kepuasan hidup dan berkualitas.

\section{Untuk Pengembangan Ilmu}

\section{Keperawatan Komunitas}

a. Pengembangan model asuhan keperawatan keluarga dan komunitas yang komprehensif dengan sistem keluarga binaan dalam konteks dukungan informasi keluarga melalui kunjungan rumah oleh perawat komunitas.

b. Perawat melakukan penelitian keperawatan dengan pendekatan eksperimen mengenai strategi intervensi keperawatan keluarga dalam meningkatkan kualitas hidup lansia hipertensi misalnya pengaruh 
pendidikan kesehatan tentang

dukungan keluarga terhadap

peningkatan kualitas hidup lansia

hipertensi.

c. Perawat melakukan penelitian keperawatan tentang pengalaman keluarga memberikan dukungan kepada lansia hipertensi dalam konteks budaya Dayak di Kalimantan Tengah.

d. Pengembangan mata ajar keperawatan komunitas berbasis keluarga oleh pengelola pendidikan.

\section{Kepustakaan}

1. Allender, Rector \& Warner (2010). Community health nursing: promotion and Protection the public's health. Philadelphia: Lippincott.

2. Anderson, E.T., \& McFarlane, J. M. (2011). Community as partner: theory and practice in nursing. Philadelphia: Wolters Kluwer Health/ Lippincott Williams \& Wilkins.

3. Ayalon L., et al. (2006). Correlates of quality of life in primary care patient with hypertension. Int'l J. Psychiatry Medicine, 36(4), 483-497.

4. Effendi F., Makhfudli (2009). Keperawatan kesehatan komunitas: teori dan praktik dalam keperawatan. Jakarta : Salemba Medika.

5. Goz, F., Karaoz, S., Goz, M., Ekiz, S., \& Cetin, I. (2007). Effect of the diabetic patient's perceived social support on their quality of life. Journal of Clinical Nursing, 16, 1353-1360.

6. Isa B.A., \& Baiyewu, O. (2006). Quality of life patient with diabetes mellitus in a Nigerian Teaching
Hospital. Hongkong Journal Psychiatry, 16, 27-33.

7. Kementerian Kesehatan Indonesia Republik Indonesia. (2011). Profil Kesehatan Indonesia 2010. Jakarta: Kementerian Kesehatan Indonesia Republik Indonesia.

8. Miller, C.A. (2004). Nursing care of older adult: theory and practice. Philadelphia: Lippincott Williams \& Wilkins.

9. Naing, MM., Nanthamongkolchai S., \& Munsawaengsub C. (2010). Quality of life of the elderly people in Einme Township Irrawaddy Division, Myanmar. Asia Journal of Public Health, 1(2), 4-10.

10. Nazir, K.A (2006). Penilaian kualitas hidup pasien pasca bedah pintas koroner yang menjalani rehabilitasi fase III dengan menggunakan SF-36. Jakarta: Universitas Indonesia.

11. Pender (1996). Health promotion in nursing practice. Stamford: Appleton \& Lange.

12. Pender, N. J., Murdaugh, C. L., \& Parsons, M. A. (2002). Health promotion in nursing practice. New Jersey: Prentice Hall.

13. Sastroasmoro, S., \& Ismael, S. (2010). Dasar-dasar metodologi penelitian klinis. Ed.3. Jakarta: Sagung Seto.

14. Stanhope, M., \& Lancaster, J. (2004). Community and public health nursing. St. Louis Missouri: Mosby.

15. Swanson, J. M, \& Nies, M. A (1993). Community health nursing : promoting the health of aggrregaes. $2^{\text {nd }}$. Philadelphia: W.B. Saunders Company.

16. Syam'ani (2011). Study fenomenologi tentang pengalaman menghadapi perubahan konsep diri: harga diri rendah pada lansia di Kecamatan Jekan Raya Kota Palangka Raya. 
Tidak dipublikasikan, Universitas Indonesia, Depok-Indonesia.

17. Taylor, S.E. (2006). Health psychology $\left(6^{\text {th }}\right.$ ed). Singapore: M.C. Grow Hill Book Company.

18. Zulfitri (2006). Hubungan dukungan keluarga dengan perilaku lanjut usia hipertensi dalam mengontrol kesehatannya di Wilayah Kerja Puskesmas Melur Tahun 2006. Tidak dipublikasikan, Universitas Indonesia, Depok-Indonesia. 